\title{
Technological Innovations in Brazil - Public Contract Legislation - A New Dimension of Sustainable Development
}

\author{
Luciana Fabiano ${ }^{1}$, Marlene Valerio dos Santos Arenas ${ }^{2}$, Rafael Vicente Martins dos Reis ${ }^{3} \&$ Lucas Rommel de \\ Souza Neves ${ }^{3}$ \\ ${ }^{1}$ Grupo de Pesquisa em Energia Renovável Sustentável (GPERS-CNPq), Programa de Mestrado Profissional em \\ Administração Pública (PROFIAP), Universidade Federal de Rondônia, Brazil \\ ${ }^{2}$ Grupo de Pesquisa Estudos Interdisciplinares em Contabilidade e Gestão Organizacional (UNIR/CNPq), Programa \\ de Mestrado Profissional em Administração Pública (PROFIAP), Universidade Federal de Rondônia, Brazil \\ ${ }^{3}$ Programa de Mestrado Profissional em Administração Pública (PROFIAP), Brazil \\ Correspondence: Luciana Fabiano, Professora da Universidade Federal de Rondônia, Grupo de Pesquisa em Energia \\ Renovável Sustentável (GPERS-CNPq), Programa de Mestrado Profissional em Administração Pública (PROFIAP), \\ Brazil.
}

Received: October 11, 2020

Accepted: November 10, 2020

Online Published: December 27, 2020

doi:10.5430/ijba.v12n1p29

URL: https://doi.org/10.5430/ijba.v12n1p29

\begin{abstract}
The study discusses the elements of technological innovation present in Law 8.666/1993 that can be considered promoters of sustainable development through public procurement. The research aims to identify elements related to “technological innovation" present in Law 8.666/1993, a public administration bidding law in Brazil, in comparison with its elements of "sustainability", which can be considered propellants of sustainable development. Based on the contribution of the bibliographic references that deal with sustainability and technological innovations, it analyzes the importance of technology in bidding as a promoter of sustainable development. It is an exploratory study; the research is bibliographic, and the method of analysis is documentary, with content analysis. The results show an elevated index of elements regarding "technological innovations" present in the text of the current legal basis, when compared to the number of elements on "sustainable development" present in the same legislation. This study proposes the consideration of technological innovation as a dimension of sustainable development, driven by Law $8.666 / 1993$, in view of the high content of referents to technological innovation present in its text.
\end{abstract}

Keywords: technological innovations, sustainable bidding, sustainable development

\section{Introduction}

Between 2010 and 2015, Brazilian Bidding Law 8.666/93 from June 21, 1993, this normatizes the purchasing activity of Brazilian public agencies in art. 3, included aspects of environmental nature, social inclusion, local development and in art. 27 dealt with the good standing of companies participating in the event regarding taxation (BRASIL, 1993).

Art. 27 of Law 8.666/1993 requires good standing regarding tax and labor laws of the participating companies as a condition to qualify for the bidding process. With the passing of Law 12.440 on July 7, 2011, participants are required to be up to date in addition to the company's tax and labor obligations; being in a state of default is not allowed.

Furthermore, law 13.146 from July 6, 2015 included in its text guaranteed preference for companies that can prove they reserve positions for people with disabilities or rehabilitated persons from Social Security. In addition to those that reserve jobs, the law also included preference for companies that prove they meet the requirements required by the law regarding accessibility (BRASIL, 1993).

In turn, Law 12.349 from December 15, 2010, this amended art. 3 of Law 8.666/1993, came about in order to highlight protection of the environment and preservation of natural resources, in which the term "sustainable" was inserted: "The bidding process is designed to guarantee the [...] promotion of sustainable national development" (BRASIL, 2010b). 
By adding the word sustainable, the law conditioned some bidding participations to adopt elements aimed at the preservation of natural resources (BRASIL, 2012). With the insertion, the expression "national development" begins to allow for hermeneutics in addition to the economic aspect, to foster the idea of development aimed at improving quality of life. It is in this context that bids can contribute to making more economical acquisitions.

Like the inclusions mentioned at the beginning of this introduction: labor rights, social inclusion of the disabled, social inclusion of retirees and preservation of the environment, the bidding law gradually acquired an increasing driving quality of public policies (CABRAL, REIS, SAMPAIO 2015; OLIVEIRA \& SANTOS, 2015; SAMPAIO, 2011). This perspective follows an international trend:

In addition to the main objective of public procurement, which is meeting the needs and demands of public administration, policymakers have shown a growing interest in using the enormous purchasing power of the public sector as a tool to support secondary objectives and political initiatives, such as green and sustainable procurements, support for small and medium-sized enterprises (SMEs) and innovation. (OBWEGESER \& MÜLLER, 2018, p. 1)

Another inclusion in Law 8.666/1993 refers to technology. The area of technology has little social accessibility and little productivity in the scope of academic productions (HAYASHI; SOUSA; ROTHBERG, 2011), especially considering the speed with which technological innovations appear and change each day.

The importance of technological innovations is on the decline today, mainly due to the need for nations, governments, organizations and individuals, to adapt to extremely fast and uninterrupted digital transformations, which shape the so-called digital age, era of knowledge and fourth industrial revolution, the economy 4.0 (ALHO \& CARVALHO, 2007; MAZZAFERRO, 2018; SOUZA \& GASPARETTO, 2018; SOUZA \& RAMOS, 2017).

The subject lacks research, studies, knowledge production in the area, in addition to more analysis on the construct that already makes up this scientific field. Herein lays the contribution of this study.

\section{Research Problem and Objective}

The following problematization motivated the study: "What elements about technological innovation, present in bidding law 8.666/93, can be considered propellers of sustainable development?" The study aims to identify elements regarding "technological innovation" present in Law 8.666/93, public administration bidding law in Brazil, in comparison to its elements of "sustainability", which can be considered as promoting sustainable development.

In order to achieve the aforementioned objective, the following specific objectives were set forth: a) to identify elements regarding technological innovation and sustainable development present in public procurement legislation; b) to create a descriptive table of the elements regarding technological innovation and sustainable development found in the bidding legislation; c) to analyze the elements of technological innovation in the described table, compared to the elements of sustainable development, in association with literature that deals with technological innovation as a promoter of sustainable development via public procurement legislation in Brazil.

Focus on the technological dimension can boost the role of promoting sustainable development through public bidding in Brazil, in view of the exponential growth of computerization in the most diverse fields of contemporary society, which justifies the study. Other legislation in the area of bidding, with the inclusion of technological innovations promoting sustainable development, may be drawn up considering the benefits of this relationship for the preservation of the environment.

\section{Theoretical Foundations}

Based on the bibliographic references that deal with sustainability and technological innovations, this section analyzes the importance of technology in tenders, as a promoter of sustainable national development.

As the original text of Law 8.666/1993 undergoes changes, it is necessary to contextualize the new understanding around these changes. Amendments to the law that "establish norms for tenders and contracts from the Public Administration", sometimes extending or suppressing part of its original content, modify its scope and applicability. In this sense, analysis of bids and contracts requires, in advance, the definition of the concepts that this study adopts as referents.

Mello (2010) discusses the origin and the concept, respectively, of what has come to be known as bidding:

Administrative procedure by which a government official, intending to transfer, acquire or lease goods, carries out jobs or services, grants concessions, work permits, services or for the exclusive use of public goods, according to conditions previously stipulated, calls for interested parties to submit proposals, in order to select the one that is most convenient based on previously established and disclosed parameters (MELLO, 2010, p. 526). 
Therefore, it is Sandri who deals with the social breadth that contracts reach (SANDRI, 2011). Due to its social context (MORAES, 2016), Law 8.666/1993 has had its art. 3 adapted, originally dated 1993:

Art. 3 The bidding process is intended to ensure compliance with the constitutional principle of isonomy, the selection of the most advantageous proposal for the administration and the promotion of sustainable national development and will be processed and judged in strict accordance with the basic principles of legality, impersonality, morality, equality, publicity, administrative probity, attachment to the summoning instrument, objective judgment and those related to them (BRASIL, 1993, emphasis added).

It is observed in the aforementioned quote that the original text of the bidding law, without the underlined and bolded parts, referred only to the instrumental, legal and technical administrative character of the bidding process. On July 19, 2010 the addition of the expression "promotion of...national development" submits the bidding law to the level of promoter of the fundamental objective of the constitution, art. 3, item II (BRASIL, 1988), that of national development. Subsequently, on December 15, 2010, the addition of the expression "promotion of...national development" with the term "sustainable", elevates the same bidding law to the status of promoter of environmental policies (BRASIL, 2010b).

The adoption of public policies aimed at the preservation of natural resources by countless countries, was one milestone among various that contributed to triggering the sustainability paradigm (ALENCASTRO, SILVA, LOPES, 2014; BRITTO, GIANNELLA, SEABRA, 2018; GUIMARÃES, VIANA, COSTA, 2015).

The word "sustainable" related to environmental sustainability, a topic discussed worldwide, referred to the bidding law as: sustainable bids (BARBOSA et al., 2018; COSTA, 2012; ROSSATO \& BELLEN, 2011), sustainable public procurement and contracts (BIAGE \& CALADO, 2015), sustainable public procurement (COUTO \& RIBEIRO, 2016), just to name a few among many authors.

The insertion of the term "sustainable" draws attention focused on public tenders as contributing to sustainable national development, but how can they contribute? Despite Normative Instruction 01/SLTI/MPOG/2010 providing environmental sustainability criteria for procurement and contracting of services by the public administration, it was Law 12.349/2010, almost a year later that defined the legal framework for sustainable bidding (CABRAL, GIESTA-CABRAL, SILVA, 2018; MORAES, 2016; VALENTE, 2011).

It is observed in the legal framework that Law 12.349/2010 is not the first legislation to add technological content to the bidding law. On August 23, 2001, Provisional Measure No. 2.182-18 instituted the type of bidding called the Auction, which in a single paragraph of art. 2nd, allowed for the realization of "auctions through the use of information technology resources" (BRASIL, 2001).

The bidding modality known as "electronic auction" carries a high innovative content, in view of the feasibility of being carried out remotely, by digital means, allowing bidders to participate in the event even if they are in another location, other than at the bidding agency:

It should be noted that a significant step in the direction of the sustainability proposal was taken with Law No. 10.520 , on July 17,2002 , which instituted the type of bidding called the auction and provided for the possibility of doing it by electronic means ( $\$ 1$ of article 2) (BRASIL, 2014, p. 7).

On the presence of innovation regarding sustainability, in an article that deals with the relationship between national development and the area of public tenders, the text by Moraes (2016) mentions the emergence of two new fields of sustainable development: the local or regional field and the technological field. The author refers to the advent of Complementary Law No. 147/2014, which made it possible for micro and small companies in the country to participate in tenders throughout Brazil:

Art. 47. In public contracts of direct and indirect, autonomous and foundational, federal, state and municipal administration, differentiated and simplified treatment should be granted to micro and small businesses aiming at promoting economic and social development at the municipal and regional level, increasing the efficiency of public policies and encouraging technological innovation. (MORAES, 2016, p. 71, emphasis added).

Like the attribution given to Complementary Law No. 147/2014, mentioned by Moraes (2016), this study considers the insertion of technological innovations in Law No. 8.666/1993 regarding the contribution of public tenders as instruments of sustainable and balanced national development to be a new dimension of sustainable development.

There are many studies that, when discussing different topics, associate technology with environmental benefits.

The largest corporate sustainability study launched in New York, for example, published by the United Nations Global Compact and Accenture Sustainability Services, points out among its main results the "Most effective use of 
technology to drive transparency, resource efficiency and a transition to a clean energy infrastructure" (BACHA; SANTOS; SCHAUN; 2010, p. 2, emphasis added).

Faria states that "sustainable development is increasingly linked to the enhancement of science, technology and innovation." (FARIA, 2018, p. 22). And the World Commission on Environment and Development (1991) itself indicates that, in order to achieve the mitigating objectives of environmental depredation, it is necessary to reorient the key link between nature and human beings, that is, technology. The Brundtland Report adds:

First, the capacity for technological innovation needs to be greatly expanded in developing countries, so that they can react more effectively to the challenges of sustainable development (WORLD COMMISSION ON ENVIRONMENT, 1991, p. 64).

Part I of the Report concludes (p. 70-71) that the pursuit of sustainable development requires several systems: political, economic, social, production, international, and administrative, each with several conditions, in addition to a technological system that constantly seeks new solutions (WORLD COMMISSION ON ENVIRONMENT, 1991).

Andrade (2004), in just the first years of the 21st century, warned about the sustainable environment being conditioned to innovation technology: "the constitution of technological paradigms that give privilege to constant innovation and decentralized diffusion are essential premises for environmental sustainability." (ANDRADE, 2004, p. 102)

Martins, Tybusch and Irigaray (2015), in addition to observing "the need to glimpse the issues of information technology as being a new paradigm in the pursuit of environmental sustainability" (MARTINS et al., 2015, p. 6), are categorical in stating that "the use of networked technologies for the benefit of environmental sustainability and biodiversity - and in this case through the use of applications - has the ability to propagate information." (MARTINS et al., 2015, p. 10). The authors go much further:

contemporary society innovates in the aspects presented, insofar as it develops technologies of the networked society that permit the practical implementation of actions that directly encourage, or influence issues related to environmental sustainability. (MARTINS et al., 2015, p. 11)

It is in this context that this study draws attention to the innovative aspect cited in the text of Law 8.666/1993 when it deals repeatedly with elements focused on technology and innovations. First and foremost, Law 8.666/1993 already plays an important role in the context of public administration tenders in Brazil. The studies by Reis and Backes (2015) discuss the participation of public purchases in the national Gross Domestic Product (GDP): "It is known that the Brazilian Government drives about 15\% of its Gross Domestic Product - GDP with the acquisition of purchases and contracting of services." (REIS \& BACKES, 2015, p. 2).

In the case of the "bidding" modality of public tenders: the legislation standardized the modality that provided for "face-to-face bidding", but it was only a single paragraph (art. $2, \S 1$ ), that "... provided for the use of technological resources ..." (BRASIL, 2002), which made public procurement "sustainable". Some authors already refer to the technological aspect of electronic bidding as a technological innovation (SOUZA; SCHRAMM; SOUSA; SOUSA, 2018), as well as the text by Freitas and Maldonado (2013). However, there are other studies that disagree with this view, such as the one carried out by Cavalcante, Silva, Centenaro and Zamberlan (2017):

Undoubtedly, face-to-face bidding is much more likely to encourage the circulation of local currency than electronic trading and it does not necessarily end with a lower discount than the electronic modality (CAVALCANTE et al., 2017, p. 136).

How does the article by Cavalcante et al. (2017) contribute to this study? Does it reveal that the technological nature of tenders must be abandoned because it is inefficient for sustainable development? On the contrary, it reveals how neglected the contribution of technological innovations is as an instrument that makes sustainability possible. Especially due to the number of other studies that reveal how beneficial the advent of technological innovations has been for the daily life of today's society, such as Santos and Sano (2016, p. 37). The authors also denounce the lack of studies on innovation directed toward the public sector:

When articles dive deep into the discussion of innovation within public management, it is common to use international literature to define innovation in the public sector. This also demonstrates a lack in the construction of concepts regarding public innovation specifically for Brazil. A concept that considers its characteristics, legislation, institutional and cultural forms. (SANTOS \& SANO, 2016, p. 46)

In line with the ideas of Santos and Sano (2016) mentioned above, this study transposes the need for studies on technological innovations to support the assertion that public tenders, as promoters of sustainability policies, will be 
more efficient when the benefits of technological innovations as a dimension of sustainable development are better understood.

\section{Methodology}

The research is bibliographic, the method of analysis is documentary and the technique is content analysis. The content analysis was structured in 5 steps according to that postulated by Laurence Bardin (2002):

1. Organization of the analysis;

2. Codification;

3. Categorization;

4. Inference;

5. Computer processing.

Following the steps listed above, this study's protocol adopted the following procedures:

1 Organization of the analysis - The scope of the data was defined. Law 8.666/1993 was chosen as the object of analysis. The context was limited to words or expressions in the body of the law's text that made any mention, directly or indirectly, of the terms "environmental sustainability" and "technological innovations";

2 Codification - The sets of words and/or expressions found in the text of Law 8.666/93 were divided into two types:

a) SDR code and

b) TIR code, which refer to sustainable development and technological innovation, respectively;

3 Categorization - Within the two coded types, SDR and TIR, the textual elements found were further subdivided into categories, with the intention of bringing together those that had some similarity in theme:

a) SDR - the 8 textual passages found were categorized as:

i) Comprehensive regarding sustainable development and

ii) Specifics about sustainable development;

b) TIR - the 25 textual passages found were classified into 5 categories:

i) Indicative of local or regional development and technological development as dimensions of sustainable development;

ii) Indicative of technology that drives transparency and resource efficiency and of a new paradigm for the search for environmental sustainability;

iii) Indicative of the driving quality of public policies and of the function of the contract aimed at social application;

iv) Indicative of the qualitative value of technological aspects and the importance of technological innovation;

v) Indicative of the valorization of technology and the incentive to move towards technological innovation.

4 Inference - interpretation of what the ordering of categories reveals about the SDR and TIR codes;

5 Computer processing - publication of the research in a high-quality international journal.

Based on the statement about sustainability being driven by law 8.666/1993 in Brazil, focusing on the approach of technological innovations as drivers of sustainable development, as well as in order to identify and describe the presence of elements regarding technological innovation in the text of Law 8.666/1993, the study protocol was created so the elements to be evaluated, the nomenclature "referents", were called analysis referents. This procedure resulted in two categories of analysis as detailed below, resulting in the data presented in sequence:

Table 1. Analysis referents created to detect elements related to sustainable development and technological innovation, present in Law 8.666/1993

\begin{tabular}{ll}
\hline Relevance & Referent \\
\hline Aspects related to sustainable development & Referent (SDR) \\
\hline Elements related to technological innovation & Referent (TIR) \\
\hline
\end{tabular}

Source: Authors' elaboration 


\section{Data Analysis and Discussion of Results}

The collected data were arranged so that they obey the order in which they appear in the original text, allowing for, as a result, the increasing disposition of articles, paragraphs, items and subparagraphs.

Table 2. Sustainable development referents (SDR) present in Law 8.666/93

\begin{tabular}{|c|c|}
\hline Item & Elements related to sustainable development - Referent (SDR) underlined \\
\hline 1 & $\begin{array}{l}\text { Art. } 3 \text { - The bidding process is designed to ensure compliance with the constitutional principle of } \\
\text { isonomy, the selection of the most advantageous proposal for the administration and the promotion of } \\
\text { sustainable national development and will be processed and judged in strict accordance with the basic } \\
\text { principles of legality, impersonality, morality, equality, publicity, administrative probity, binding to the } \\
\text { summoning instrument, objective judgment and those related to them. (Redaction from Law No. } \\
12.349 \text {, of 2010) }\end{array}$ \\
\hline 2 & $\begin{array}{l}\text { Art. } 3 \S 5 \text { In bidding processes, a margin of preference may be established for: } \\
\text { I - manufactured products and for national services that meet Brazilian technical standards; and } \\
\text { (Included by Law No. 13.146/2015) }\end{array}$ \\
\hline 3 & $\begin{array}{l}\text { Art. } 3 \S 7 \text { For manufactured products and national services resulting from technological development } \\
\text { and innovation carried out in the Country, a margin of preference may be established in addition to that } \\
\text { provided for in } \S 5 \text {. (Included by Law No. 12.349/2010) (See Decree No. 7.546/2011) }\end{array}$ \\
\hline 4 & $\begin{array}{l}\text { Art. } 6 \text { For the purposes of this Law, it is considered that: } \\
\text { XVII - nationally manufactured products - manufactured products, produced in the national territory } \\
\text { according to the basic production process or with the rules of origin established by the Federal } \\
\text { Executive Branch; (Included by Law No. 12.349/2010) }\end{array}$ \\
\hline 5 & $\begin{array}{l}\text { Art. 12. In the basic projects and executive projects of works and services, the following requirements } \\
\text { will be primarily considered: (Redaction from Law no. 8.883/1994) } \\
\text { VII - environmental impact. }\end{array}$ \\
\hline 6 & $\begin{array}{l}\text { Art. 17. The sale of Public Administration assets, subject to the existence of a duly justified public } \\
\text { interest, will be preceded by an assessment and will obey the following rules: } \\
\text { III - prohibition of concessions for exploratory purposes not contemplated in the agrarian law, in the } \\
\text { laws of destination for public lands, or in the legal or administrative norms of ecological-economic } \\
\text { zoning; and (Included by Law No. 11.196/2005) }\end{array}$ \\
\hline 7 & $\begin{array}{l}\text { Art. 24. Bidding is not necessary: } \\
\text { XXVII - contracting for the collection, processing and sale of recyclable or reusable urban solid waste, } \\
\text { in areas with a selective garbage collection system, carried out by associations or cooperatives formed } \\
\text { exclusively by low-income individuals recognized by the government as recyclable material collectors, } \\
\text { with the use of equipment compatible with technical, environmental and public health standards. } \\
\text { (Redaction from Law No. 11.445/2007). }\end{array}$ \\
\hline 8 & $\begin{array}{l}\text { place or object to carry out the } \\
\text { sources of natural materials }\end{array}$ \\
\hline
\end{tabular}

Source: Authors' elaboration

Sustainable development referents (SDR) appear in the bidding law eight times. The terms found fall into two categories: a) comprehensive: in the sense of encompassing the whole, involving different sectors, different aspects and b) specific: in the sense of being restricted to some sectors, focused on some aspects, namely: (i) four comprehensive: one "sustainable national development", two "environmental impact", three "environmental" and four "natural materials"; (ii) four specific: one "manufactured products", "national manufactured products", two "ecological-economic zoning", three "collection, processing and sale of recyclable or reusable urban solid waste", "selective garbage collection", four "recyclable materials". 
The eight SDR found in "Table 2" mention the promotion of sustainable environmental development and therefore motivate its occurrence, as in the example of Alencastro et al. (2014); Britto et al. (2018); Guimarães et al. (2015) mentioned in this article, when Law 8.666/1993 was instituted as a driver of public policy; as mentioned by Moraes (2016) also in this study, Brazil also carried out public policy aimed at the preservation of natural resources, contributing to the triggering of the sustainability paradigm.

The elements from the "specific" category likewise promote sustainable development when they define "manufactured products" or "national manufactured products" as preferred. By choosing hand-made products only in the manufacturing process, large-scale production is prevented, which causes the waste of natural resources.

Table 3. Technological innovation referents present in Law 8.666/1993

\begin{tabular}{|c|c|}
\hline Item & Elements related to technological innovation - Referent (TIR) underlined \\
\hline \multirow[t]{2}{*}{1} & $\begin{array}{l}\text { Art. } 3 \S 2 \text { Under equal conditions, as a tiebreaker criterion, preference will be given, successively, to } \\
\text { goods and services: }\end{array}$ \\
\hline & $\begin{array}{l}\text { IV - produced or provided by companies that invest in research and technological development in the } \\
\text { Country. (Included by Law No. } 11.196 / 2005 \text { ) }\end{array}$ \\
\hline \multirow[t]{2}{*}{2} & $\begin{array}{l}\text { Art. } 3, \S 6 \text { The preference margin referred to in } \S 5 \text { will be established based on periodically reviewed } \\
\text { studies, within a period not exceeding } 5 \text { (five) years, which take into account: (Included by Law No. } \\
\text { 12.349/2010) (See Decree No. 7.546/2011) (See Decree no. 7.709/2012) (See Decree no. 7.713/2012) } \\
\text { (See Decree no. 7.756/2012) }\end{array}$ \\
\hline & III - technological development and innovation carried out in the Country; \\
\hline 3 & $\begin{array}{l}\text { Art. } 3, \S 7 \text { For manufactured products and national services resulting from technological } \\
\text { development and innovation carried out in the Country, a margin of preference may be established in } \\
\text { addition to that provided for in } \S 5 \text {. (Included by Law No. 12.349/2010) (See Decree No. 7.546/2011) }\end{array}$ \\
\hline 4 & $\begin{array}{l}\text { Art. } 3, \S 11 \text {. The bidding documents for the contracting of goods, services and works may, upon prior } \\
\text { justification by the competent authority, require that the contractor promote, in favor of an agency } \\
\text { or entity that is part of the public administration or of those indicated by it through an isonomic } \\
\text { process, commercial, industrial, technological compensation measures or access to advantageous } \\
\text { financing conditions, cumulatively or not, in the form established by the federal executive branch. } \\
\text { (Included by Law no. 12.3492010) (See Decree no. } 7.546 / 2011 \text { ) }\end{array}$ \\
\hline
\end{tabular}

5 Art. $3, \S 12$. In contracts for the implementation, maintenance and improvement of information and communication technology systems, considered strategic in the act of the federal Executive Branch, the bidding may be restricted to goods and services with technology developed in the Country and produced according to the basic production process that Law 10.176, from January 11, 2001 deals with. (Included by Law No. 12.3492010) (See Decree No. 7.546/2011)

$6 \quad$ Art. $3, \S 13$. The list of companies favored as a result of the provisions in $\S \S 5,7,10,11$ and 12 of this article will be disclosed on the internet for each financial year, with an indication of the volume of resources allocated to each of them. (Included by Law No. 12.349/2010)

7 Art. 6 For the purposes of this Law, it is considered that:

XIX - strategic information and communication technology systems - information and communication technology goods and services whose discontinuity causes significant damage to public administration and which involves at least one of the following requirements related to critical information: availability, reliability, security and confidentiality. (Included by Law No. 12.349/2010)

8 Art. 6, XX - products for research and development - goods, supplies, services and jobs necessary for scientific and technological research, technology development or technological innovation activities, listed in a research project approved by the contracting institution. (Included by Law No. 13.2432016)

9 Art. 12. In basic projects and executive projects of works and services, the following requirements will primarily be considered:

IV - possibility of using labor, materials, technology and raw materials that exist in the place of 


\section{Item Elements related to technological innovation - Referent (TIR) underlined}

execution, conservation and operation;

10 Art. 15. Purchases, whenever possible, must:

$\S 5$ The control system originated in the general price chart, when possible, must be computerized.

11 Art. 21. The notices containing the bidding notice summaries, submission of prices, tenders and auctions, even when carried out at the location of the interested office, must be published in advance at least once:

III - on the official website of the respective federative entity, made available to the States, the Federal District and the Municipalities, or alternatively, through the use of the official Union website, according to the regulations of the Federal Executive Branch. (Redaction from Provisional Measure No. 896, of 2019)

12 Art. 24. Bidding is not necessary:

XVI - for the printing of national gazettes, standardized forms for use by the administration, and official technical editions, as well as for the provision of computer services to legal entities under internal public law, by agencies or entities that are part of the Public Administration, created for this specific purpose; (Included by Law No. 8.883/1994)

13 Art. 24 XXV - when hired by a Scientific and Technological Institution - STI or by a promotion agency for the transfer of technology and for the licensing of the right to use or exploit a protected creation. (Included by Law No. 10.973/2004)

14 Art. 24 XXVIII - for the supply of goods and services, produced or rendered in the Country, which, cumulatively involve high technological complexity and national defense, based on the opinion of a commission specially designated by the highest authority of the agency. (Included by Law No. 11.4842007).

15 Art. 24 XXXII - when hiring involves technological transfer of strategic products to the Unified Health System - SUS, within the scope of Law 8.080, from September 19, 1990, as listed in the act of the national director of SUS, including when purchasing these products during the technological absorption stages.

16 Art. 24 XXXIII - in hiring private non-profit entities, for the implementation of cisterns or other social technologies for access to water for human consumption and food production, to benefit low-income rural families affected by drought or regular lack of water.

17 Art. 24 XXXIV - for the acquisition by a legal entity of internal public law of strategic inputs for health, produced or distributed by a foundation that, regimentally or statutorily, has the purpose of supporting a direct public administration body, its autarchy or foundation in teaching, research, extension, institutional, scientific and technological development projects and those stimulating innovation, including in the administrative and financial management necessary for the execution of these projects, or in partnerships involving the transfer of technology from strategic products to the Unified Health System - SUS, under the terms of item XXXII in this article, and that was created for that specific purpose on a date prior to the effectiveness of this Law, provided that the contracted price is compatible with that practiced in the market. (Included by Law No. 13.204/2015)

18 Art. 30. Technical qualification documentation will be limited to:

$\S 3^{\circ}$ Proof of aptitude through certificates or testimonials of similar projects or services of equivalent or higher technological and operational complexity will always be admitted.

19 Art. 32. The documents required for qualification may be presented as originals, as a certified copy through any process by a competent notary or by a government official or publication in an official press agency. (Redaction from Law no. 8.883, of 1994)

$\S 2$ The registration certificate referred to in $\S 1$ of art. 36 replaces the documents listed in art. 28 through 31 , regarding the information provided in a direct consultation computerized system indicated in the notice, obliging the party to declare, under legal penalties, the occurrence of a fact that 


\section{Item Elements related to technological innovation - Referent (TIR) underlined} impedes the qualification. (Redaction from Law No. 9.648/1998)

20 Art. 34. For the purposes of this Law, the agencies and entities of the Public Administration that frequently carry out bids will maintain registration records for the purpose of qualification, in the regulatory form, valid for a maximum of one year. (Regulation)

$\S 1$ The cadastral register must be widely disseminated and must be permanently open to interested parties, the unit responsible for it being obliged to proceed, at least annually, through the official press and the official website, to the public call for updates on existing records and the entry of new interested parties. (Redaction from Provisional Measure No. 896/2019)

21 Art. 45. § 4 In order to hire computer goods and services, management will observe the provisions of art. 3 of Law No. 8.248, from October 23, 1991, taking into account the factors specified in its 2nd paragraph and obligatorily adopting the type of bidding known as "technical and price", permitting the use of another type of bidding in cases indicated by decree from the Executive power. (Redaction from Law no. 8.883/1994)

22 Art. 46. § 1 In "best technical" bids, the following procedure will be clearly explained in the invitation to bid, which will set out the maximum price that the Administration proposes to pay:

I - only the envelopes containing technical proposals from qualified bidders will be opened and then the evaluation and classification of these proposals will be carried out according to the relevant and appropriate criteria for the object being bid upon, defined clearly and objectively in the invitation to bid and which consider the proposer's experience and training, the technical quality of the proposal, including methodology, organization, technologies and material resources to be used in the projects, and the qualification of the technical teams to be mobilized for its execution;

23 Art. $46 \S 3$ Art. $46 \S 3$ Exceptionally, the types of bidding provided for in this article may be adopted, by express authorization and upon detailed justification by the highest authority of the promoting Administration included in the invitation to bid, for the supply of goods and the execution of projects or the provision of services majorly dependent on clearly sophisticated technology and restricted domain, attested by technical authorities with recognized qualifications, in cases where the intended object admits alternative solutions and variations in execution, with significant repercussions regarding its concretely measurable quality, productivity, performance and durability, and these can be adopted at the free choice of the bidders, in accordance with the criteria objectively set forward in the call notice.

24 Art. 57. The duration of the contracts governed by this Law will be restricted to the term of the respective budget credits, except for those relating to:

IV - the rental of equipment and the use of computer programs, the duration of which may extend up to 48 (forty-eight) months after the beginning of the contract.

25 Art. 111. The Administration can only hire, pay, award or receive a project or specialized technical service as long as the author gives up the patrimonial rights related to it and the Administration can use it in accordance with the provisions of the competition rules or in the adjustment for its preparation.

Single paragraph. When the project refers to immaterial work of a technological nature, insusceptible to privilege, the assignment of rights will include the provision of all data, documents and information elements relevant to the technology of design, development, fixation in physical support of any nature and application of the project.

Source: Authors' elaboration

The 25 TIRs identified in "Table 3" can be considered elements promoting sustainable development.

Upon analysis of "Table 3", items 2; 3; 5; 9 and 14 give preference to national and local companies that establish a relationship with the technological aspect, in line with the statement by Moraes (2016), cited in this study, indicating local or regional development and technological development as dimensions of sustainable development. 
Items 6; 7; 11; 19 and 20 from "Table 3" are indicative of dissemination, information, communication and notice by electronic means; the studies by Bacha et al. (2010) presented herein legitimize the authors' statement about technology boosting transparency and resource efficiency. Furthermore, the same items agree with the ideas of Martins et al. (2015) in this study regarding a new paradigm in the pursuit of environmental sustainability.

Items 4; 15; 16 and 17 from "Table 3", mention technological compensation measures, the Unified Health System (SUS) and social technologies regarding access to water to benefit low-income rural families, affected by drought or regular lack of water; they do so by revealing the driving quality of public policies made possible by Law 8.666/1993, regarding what Cabral et al. (2015); Oliveira, Santos (2015) and Sampaio (2011) claim in this study, on the bidding law, with emphasis, this time on the relationship with the technological aspect. Still, on the same items 4; 15; 16 and 17, the function of the contract focused on social application, mentioned by Sandri (2011), can be transposed here.

Items $18 ; 22$ and 23 , from the same table, characterize the qualitative value of the conditions and standards set forth by Law 8.666/1993 whenever related to the technological aspect. These points in the text: a) in item 18 - "technical qualification" related to "technological complexity"; b) in item 22 - "best technology" related to "technical quality", related to "technologies"; c) in item 23 - "services majorly dependent on clearly sophisticated technology" associated with the expression "certified by recognized technical authorities", act as elements to highlight the importance of technological innovation, which contributes to sustainable development, according to the connection between the latter and technology, in agreement with Faria (2018).

In turn, the preferential nature (item 1), the (almost) imperative nature of duty (item 10), the dismissal nature (items 12; 13), preferably in compliance with art. 3 of Law 8.248/1991 (item 21), the exemptive nature (item 24) and the conditional-inclusive nature (item 25) attributed respectively to the technological factors in "Table 3", in addition to reinforcing the appreciation of technology, mentioned by Faria (2018), configure incentives for technological innovation, as indicated here in a quote from the World Commission on Environment and Development (1991), as a way to expand the innovation capacity of developing countries.

In this sense, Law 8.666/1993 composes, as a tool, the technological system of Brazil and establishes a relationship with the system mentioned in the foundation of this study, by the Brundtland Report itself, as a condition to achieve sustainable development.

Sustainable development referents (SDR) appear in Law 8.666/1993 eight times. In contrast, technological innovation referents (TIR) appear in the same legislative text 25 (twenty-five) times, 17 (seventeen) times more.

One relevant point deserves to be noted regarding the sustainable bidding framework in Brazil: Law 12.349/2010 makes only one mention of the environmental aspect, namely: the word "sustainable" inserted in art. 3 mentioned at the beginning of this study. On the other hand, the other subdivisions of Law 12.349/2010 are full of terms related to innovation and technology added to the bidding law, Law 8.666/1993, namely:

Table 4. Elements of technological innovation present in Law 12.349/2010

\begin{tabular}{ll}
\hline Part of legislation & Terms relating to technological innovations \\
\hline Item III of $\S 6$ of art. 3 & {$[\ldots]$ technological development and innovation $[\ldots] ;$} \\
\hline$\S 7$ of art. 3 & {$[\ldots]$ technological development and innovation $[\ldots] ;$} \\
\hline$\S 11$ of art. 3 & {$[\ldots]$ technological $[\ldots]$ compensation measures $[\ldots] ;$} \\
\hline$\S 12$ of art. 3 & {$[\ldots]$ information and communication technology systems $[\ldots]$} \\
& services with technology developed in the Country $[\ldots] ;$ \\
\hline$\S 13$ of art. 3 & {$[\ldots]$ published on the internet $[\ldots] ;$} \\
\hline Item XIX of art. 6 & {$[\ldots]$ strategic information and communication technology systems } \\
& {$[\ldots] ;$} \\
\hline Item XXI of art. 24 & {$[\ldots]$ scientific and technological research $[\ldots]$} \\
\hline
\end{tabular}

Source: Authors' elaboration

Like Law 12.349/2010 which the authors (CABRAL et al. 2018; MORAES, 2016; VALENTE, 2011), cited in the framework of this study, highlight as the legal basis that defined the framework for sustainable bidding, their text 
only mentions the environmental aspect once, even though this landmark law is meaningful since the point in time when it was established, it is possible that the consideration of the high number of "TIR" referents in relation to the smaller number of "SDR" referents present in Law 8.666/1993, may contribute to its meaning as legal basis in the promotion of sustainable development, made possible by the technological aspect, much more than by the environmental aspect.

In turn, just as the "auction" law, Law 10.520/2002 also made "sustainable" public procurement possible through just one paragraph in its art. 2 ( $(1)$; this study believes that the 25 passages $(25$ TIRs) found in "Table 3" incite a discussion about the technological aspect in the promotion of sustainable development promoted by Law 8.666/1993.

It is worth remembering that, as discussed by Souza et al. (2018) or Freitas and Maldonado (2013) on the existence of the technological aspect of the auction as a technological innovation in public administration tenders, there is, in the same way, the technological aspect of Law 8.666/1993.

In time, articles such as that by Cavalcante et al. (2017), cited in this study, who defend face-to-face trading as a promoter of sustainable development, much more than trading in its electronic modality, due to the valorization of the local economy, receive positive reinforcement, even if indirectly. They may still be confronted again, due to the insistence on the technological nature of tenders in the promotion of sustainable development, even if promoted by another law, but which is likewise based on public purchases.

The innovative aspect of the technologies, ubiquitous in the text of Law 8.666/1993, is an element capable of making desired environmental sustainability viable. This assertion is found in diverse international publications, which establish various relationships between public procurement, innovation and environmental sustainability.

A report by the Organization for Economic Cooperation and Development (OECD) shows that innovation has become an additional and important strategy pursued by public authorities when making decisions regarding public procurement. OECD member countries have come to consider not only financial value as a benchmark for quality in public procurement, but are gradually including more strategic objectives, such as innovation and environmental aspects (APPELT \& GALINDO-RUEDA, 2016).

A publication on public procurement by the German Federal Ministry for Economic Affairs and Energy, when conceptualizing the meaning of innovation, does so in a way that enhances its relationship with sustainability: in "promoting innovation in public procurement [...] Goals such as conservation of natural resources and energy efficiency are closely linked to innovation" (BMWi, 2017, p. 5).

In the United States, the state of Texas follows a trend observed in federal agencies of that country: "it aims at innovation through purchases, in order to serve other social purposes, such as energy conservation and of the environment" (VONORTAS; BHATIA; MAYER, 2011, p. 13). "The tendency to develop innovations in pursuit of a social cause is more visible in the environmental sector than anywhere else" (VONORTAS et al.; 2011, p. 14).

\section{Conclusion}

This study attained its proposal to identify elements related to "technological innovation" present in Law 8.666/1993, a Brazilian public administration bidding law, in comparison with its elements of "sustainability", which can be considered as promoting sustainable development.

The results indicate an elevated index of elements regarding technological innovations present in Law 8.666/1993, in total 25 , against 8 related to sustainability, and these elements, when analyzed individually, establish a relationship that goes against theories that envision sustainable development facilitated by technologies. When considering the benefits of this relationship, the inclusion of aspects of technological innovation in legislative texts regarding public tenders may be given more priority.

This study has limitations since it proposes to analyze only Law 8.666/1993; future research should be expanded and applied to other laws that establish the relationship between tenders and sustainable development.

We propose new studies addressing other laws that were not included in the scope of this study, such as: Constitution of the Federative Republic of Brazil of 1988; Law 10.520/2002; Normative Instruction 01//2010; Law 12.349/2010 and Decree 7.746//2012 or international public procurement legislation.

This study contributes to filling a gap in the literature regarding a discussion on sustainability made possible by innovation in public procurement. Another contribution includes fundamentals and approaches on stimulating sustainability and innovation through public contracts. In the same way, the scientific literature recognizes the need to discuss instruments of innovation policies, which, in this article, is presented in the form of analysis of the legal basis on public procurement. In this sense, a large part of the publication comes from Europe, but interest is growing 
in other countries such as Australia, China, Japan and the United States. A comprehensive discussion surrounding these aspects lacks theoretical and scientific dialogue about sustainability made possible by stimulating innovation through public procurement.

The technological aspect, in this sense, deserves to receive more attention from scholars, researchers, legislators, managers and stakeholders when dealing with sustainable public tenders. The phenomenon of technological innovations, related to public procurement, may be being neglected, through a greater number of publications that show ever more the sustainable aspect of tenders without discussing the relevant participation of technological innovations in promoting this sustainable development.

Under no circumstances should the supremacy of sustainable development be disregarded over, for the time being, technological innovations. However, it is a question of highlighting the usefulness of technological innovations, of turning more attention to what, perhaps, could be a more successful alternative, in the solution of the numerous problems arising from attempts to attain the desired sustainable development.

The study also highlights the possibility of considering technological innovations as a new dimension of sustainable development, given their considerable presence in the legal bases related to Law 8.666/93, which contribute to the promotion of sustainable development in Brazil.

Just as the phenomenon of technological innovations has increasingly engendered the social, political, economic, cultural, and environmental segments along with others, its insertion in the field of bidding is also visible and increasingly growing. In this sense, it is opportune to pay attention to the adequacy of the theoretical discussions of sustainable bids by updating the technological bias, in order to promote sustainable development.

\section{References}

Alencastro, M. A. C., Silva, E. V. Da., \& Lopes, A. M. D. Á. (2014). Contratações sustentáveis na administração pública brasileira: a experiência do poder executivo federal. Rio de Janeiro, 48(1), 207-35. Retrieved from http://bibliotecadigital.fgv.br/ojs/index.php/rap/article/view/16072

Alho, M. R., \& Carvalho, P. A. M. de. (2007). Tecnologia da informação e os novos modelos de gestão de pessoas. Brasília. Retrieved from https://portal.tcu.gov.br/biblioteca-digital/tecnologia-da-informacao-e-os-novos-modelos-de-gestao-de-pessoas. htm

Andrade, T. (2004). Inovação tecnológica e meio ambiente: a construção de novos enfoques. Ambiente \& Sociedade, 7(1). Retrieved from https://www.scielo.br/pdf/asoc/v7n1/23538.pdf

Appelt, S., \& Galindo-Rueda, F. (2016). Measuring the Link between Public Procurement and Innovation. OECD Science, Technology and Industry Working Papers, 2016/03. OECD Publishing, Paris. https://doi.org/10.1787/5jlvc7s11w7h-en.

Bacha, M. De. L., Santos, J., \& Schaun, A. (2010). Considerações teóricas sobre o conceito de Sustentabilidade. VII SEGeT - Simpósio de Excelência em Gestão e Tecnologia. Retrieved from https://www.aedb.br/seget/arquivos/artigos10/31_cons\%20teor\%20bacha.pdf

Barbosa, A. C., Oliveira, A. S. De. L., Arenas, M. V. Dos. S., \& Bisinoto, G. D. S. (2018). Licitação sustentável na administração pública: um estudo de caso no tribunal regional do trabalho - 14a região. Revista Gestão \& Sustentabilidade Ambiental, Florianópolis, 7(3), 435-453. https://doi.org/10.19177/rgsa.v7e32018435-453

Bardin, Laurence. Análise de conteúdo. (2002). Tradução: Luís Antero Reto e Augusto Pinheiro do original intitulado " $L$ ' Analyse de Contenu" de 1977. Lisboa, Portugal: Edições 70, 2002. Retrieved from https://www.ets.ufpb.br/pdf/2013/2\%20Metodos\%20quantitat\%20e\%20qualitat\%20-\%20IFES/Bauman,\%20Bo urdieu,\%20Elias/Livros\%20de\%20Metodologia/Bardin\%20-\%201977\%20-\%20An\%C3\%A1lise\%20de\%20Co nte\%C3\%BAdo.pdf.

Biage, V. S. M. De., \& Calado, L. R. (2015). Análise dos resultados das contratações públicas sustentáveis. REAd, Porto Alegre, 82(3), 601-620. https://doi.org/10.1590/1413-2311.0612014.54781

BMWi, \& Federal Ministry for Economic Affairs and Energy. (2017). Public procurement of innovation (2nd ed.). Berlim: Druck-und Verlagshaus Zarbock GmbH \& Co.KG, Frankfurt. Retrieved from https://procure2innovate.eu/fileadmin/user_upload/Documents/KOINNO_PublicProcurementofInnovation.pdf 
Britto, F. G. A. De., Giannella, L. De. C., \& Seabra, R. Dos. S. (2018). Análise ambiental e gestão do território: contribuições teórico-metodológicas. Rio de Janeiro: IBGE. Retrieved from https://biblioteca.ibge.gov.br/biblioteca-catalogo.html?id=2101623\&view=detalhes

Brasil, Presidência da República. (1988). Constituição da República Federativa do Brasil de 1988. Brasília: [s. n.]. Retrieved from http://www.planalto.gov.br/ccivil_03/Constituicao /Constituicao.htm

Brasil, Presidência da República. (1991). Lei No 8.248 de 23 de outubro de 1991. Brasília: [s. n.]. Retrieved from http://www.planalto.gov.br/ccivil_03/leis/L8248compilado.htm

Brasil, Presidência da República. (1993). Lei $N^{o} 8.666$ de 21 de junho de 1993. Brasília: [s. n.]. Retrieved from http://www.planalto.gov.br/ccivil_03/Leis/L8666cons.htm

Brasil, Presidência da República. (2001). Medida Provisória No 2.182-18 de 23 de agosto de 2001. Brasília: [s. n.]. Retrieved from https://www2.camara.leg.br/legin/fed/medpro/2001/medidaprovisoria-2182-18-23-agosto-2001-389644-publica caooriginal-1-pe.html

Brasil, Presidência da República. (2002). Lei $N^{o} 10.520$ de 17 de julho de 2002. Brasília: [s. n.]. Retrieved from http://www.planalto.gov.br/ccivil_03/leis/2002/L10520.htm

Brasil, Presidência da República. (2010a). Secretaria de Logística e Tecnologia da Informação do Ministério do Planejamento, Orçamento e Gestão. Instrução Normativa $N^{o} 01$ de 19 de janeiro de 2010. Brasília: [s. n.]. Retrieved from https://www.gov.br/governodigital/pt-br/legislacao/IN01de2010ComprasSustentaveis.pdf

Brasil, Presidência da República. (2010b). Lei $N^{o} 12.349$ de 15 de dezembro de 2010. Brasília: [s. n.]. Retrieved from http://www.planalto.gov.br/ccivil_03/_ato2007-2010/2010/lei/L12349.htm

Brasil, Presidência da República. (2011a). Lei $N^{o} 12.440$ de 7 de julho de 2011. Brasília: [s. n.]. Retrieved from http://www.planalto.gov.br/ccivil_03/_Ato2011-2014/2011/Lei/L12440.htm

Brasil, Presidência da República. (2011b). Decreto $N^{o} 7.546$ de 2 agosto de 2011. Brasília: [s. n.]. Retrieved from http://www.planalto.gov.br/ccivil_03/_ato2011-2014/2011/decreto/ D7546.htm

Brasil, Presidência da República. (2012). Decreto $N^{o} 7.746$ de 5 de junho de 2012. Brasília: [s. n.]. Retrieved from http://www.planalto.gov.br/ccivil_03/_ato2011-2014/2012/decreto/D7746.htm

Brasil, Presidência da República. (2014). Lei Complementar $N^{o} 147$ de 7 de agosto de 2014. Brasília: [s. n.]. Retrieved from http://www.planalto.gov.br/ccivil_03/leis/lcp/Lcp147.htm

Brasil, Presidência da República. (2015). Lei $N^{o} 13.146$ de 6 de julho de 2015. Brasília: [s. n.]. Retrieved from http://www.planalto.gov.br/ccivil_03/_ato2015-2018/2015/lei/L13146.htm

Cabral, R. L. G., Giesta-Cabral, L. C., \& Silva, C. G. da. (2018). Promoção de desenvolvimento sustentável no nível municipal: uma análise da dispensa de licitação na coleta seletiva de resíduos frente a agenda 2030. Revista de Direito da Cidade, 10(4), 2736-2769. https://doi.org/10.12957/rdc.2018.34702

Cabral, S., Reis, P. R. D. C., \& Sampaio, A. D. H. (2015). Determinantes da participação e sucesso das micro e pequenas empresas em compras públicas: uma análise empírica. R. Adm., São Paulo, 50(4), 477-491. https://doi.org/10.5700/rausp1214

Cavalcante, S. D. O. R., Silva, L. I. D. P. D., Centenaro, M., \& Zamberlan, C. O. (2017). Análise do pregão eletrônico e presencial na Universidade Estadual de Mato Grosso do Sul. Revista Práticas de Administração Pública. Santa Maria, l(1), 119-138. $\quad$ Retrieved from https://periodicos.ufsm.br/pap/article/download/25878/15333

Comissão Mundial Sobre o Meio Ambiente e Desenvolvimento. (1991). Nosso futuro comum (2nd ed.). Rio de Janeiro: FGV. Retrieved from https://docero.com.br/doc/n5svs5c

Costa, C. E. L. D. (2012). As licitações sustentáveis na ótica do controle externo. Interesse Público - IP. Biblioteca Digital. Belo Horizonte: Fórum Ano, 14(71). Retrieved from https://portal.tcu.gov.br/biblioteca-digital/as-licitacoes-sustentaveis-na-otica-do-controle-externo.htm

Couto, H. L. G. D., \& Ribeiro, F. L. (2016). Objetivos e desafios da política de compras públicas sustentáveis no Brasil: a opinião dos especialistas. Rev Adm Pública, Rio de Janeiro, 50(2), 331-343. https://doi.org/10.1590/0034-7612146561 
Faria, A. F. D. (2018). O que é "inovação", seus tipos, e como tal fenômeno relaciona-se com uma forte estrutura institucional para o desenvolvimento científico. In S. F. D. Menezes, \& P. E. K. Eyng (Eds.), Marco regulatório em ciência, tecnologia e inovação: texto e contexto da lei n. 13.243/2016. Belo Horizonte: Arraes. Retrieved from

http://www.centev.ufv.br/Recursos/Imagens_CK/files/518_MARCOREGULATORIOEMCIENCIATECNOLO GIAEINOVACAO_PDF_ONLINE-compactado.pdf

Freitas, M. D., \& Maldonado, J. M. S. D. V. (2013). O pregão eletrônico e as contratações de serviços contínuos. Revista de Administração Pública, Rio de Janeiro, 47(5), 1265-1282. Retrieved from http://bibliotecadigital.fgv.br/ojs/index.php/rap/article/view/ 12052

Guimarães, C., Viana, L. S., \& Costa, P. H. D. S. (2015). Os desafios da consciência ambiental: o marketing verde em questão. C@LEA - Cadernos de Aulas do LEA, (4), 94-104. Retrieved from http://www.uesc.br/revistas/calea/edicoes/rev4_artigo7.pdf

Hayashi, M. C. P. I., Sousa, C. M. D., \& Rothberg, D. (2011). Apropriação social da ciência e da tecnologia: contribuições para uma agenda [online]. Campina Grande: EDUEPB. Retrieved from http://books.scielo.org/id/j76hp/pdf/hayashi-9788578 791872.pdf

Martins, E. J., Tybusch, F. B. A., \& Irigaray, M. C. (2015). Informação ambiental e as novas tecnologias: alternativas sustentáveis para a problemática dos resíduos sólidos. In $3^{\circ}$ Congresso Internacional de Direito $e$ Contemporaneidade: mídias e direitos da sociedade em rede. Santa Maria - RS, 27-29 maio. Retrieved from http://coral.ufsm.br/congressodireito/anais/2015/5-5.pdf

Mazzaferro, J. A. E. (2018). Indústria 4.0 e qualidade da informação. Soldag Insp São Paulo, 23(1), 1-2. https://doi.org/10.1590/0104-9224/si2301.01

Mello, C. A. B. D. (2010). Curso de direito administrativo (27th ed.). Revista e atualizada até a Emenda Constitucional 64 de 4 fev. São Paulo: Malheiros. Retrieved from https://www.academia.edu/36527437/Direito_Administrativo_-_Celso_Ant\%C3\%B4nio_Bandeira_de_Mello.p df?auto=download

Moraes, C. (2016). Desenvolvimento nacional, licitações e fiscalização pelos tribunais de contas. Revista do Tribunal de Contas da União. Brasília Ano, 48(136), 67-76. Retrieved from https://revista.tcu.gov.br/ojs/index.php/RTCU/article/view/1360

Nikolaus, O., \& Sune Dueholm, M. (2018). Innovation and public procurement: Terminology, concepts, and applications. ScienceDirect. https://doi.org/10.1016/j.technovation.2018.02.015

Oliveira, B. C. S. C. M. D., \& Santos, L. M. L. D. (2015). Compras públicas como política para o desenvolvimento sustentável. Rev Adm Pública Rio de Janeiro, 49(1), 189-206. https://doi.org/10.1590/0034-76121833

Reis, L. E., \& Backes, C. (2015). A licitação pública e sua finalidade de promover o desenvolvimento nacional sustentável. Revista de Estudos Jurídicos UNESP, Franca, Ano, 19(30), 1-19. Retrieved from https://ojs.franca.unesp.br/index.php/estudosjuri dicosunesp/article/view/1590/1883

Rossato, J., \& Bellen. H. M. V. (2011). Licitações Sustentáveis: um levantamento das iniciativas adotadas na administração pública. In $X X X V$ Encontro da ANPAD - EnANPAD. Rio de Janeiro: [s. n.]. Retrieved from http://www.anpad.org.br/admin/pdf/ESO2131.pdf

Sampaio, R. A. (2011). A nova Lei $n^{\circ} 8.666 / 93$. A Lei no $12.349 / 10$ e a indução de políticas públicas para promover o desenvolvimento nacional sustentável. Revista Jus Navigandi, Teresina, Ano, 16(2813). Retrieved from https://jus.com.br/artigos/18687

Sandri, J. S. (2011). Função social do contrato. Conceito. Natureza jurídica e fundamentos. Revista de Direito Público, Londrina, $\quad 6(2), \quad 120-141 . \quad$ Retrieved $\quad$ from http://www.uel.br/revistas/uel/index.php/direitopub/article/viewFile/8721/ 9062

Santos, F. J. S. D., \& Sano, H. (2016). Inovação no setor público: um olhar sobre os estudos brasileiros. Revista Interface. Edição $\quad$ especial. Natal/RN, 13(2). $\quad$ Retrieved from https://ojs.ccsa.ufrn.br/index.php/interface/article/view/712

Souza, E. S. D., \& Gasparetto, V. (2018). Características e impactos da indústria 4.0: percepção de estudantes de ciências contábeis. In XXV Congresso Brasileiro de Custos. Vitória/ES. Brasil. Retrieved from https://anaiscbc.emnuvens.com.br/ anais/article/view/4570/4571 
Souza, H. B. D., Schramm, G. M. R., Sousa, H. L. D., \& Sousa, M. D. C. D. (2018). As vantagens na utilização do pregão eletrônico nas compras públicas sustentáveis. In Congresso Internacional de Administração - ADM

Sucre

Bolívia.

Retrieved

from https://admpg2018.com.br/wp-content/uploads/trabalhos_aprovados/index.html

Souza, L. A. M. D., \& Ramos, N. C. S. (2017). Indústria 4.0: uma revisão sistemática da literatura nacional. In XXXVII Encontro Nacional de Engenharia De Produção - ENEGEP. Joinville - SC: Associação Brasileira de Engenharia de Produção. $\quad$ Retrieved http://www.abepro.org.br/publicacoes/artigo.asp?e=enegep\&a=2017\&c=31632

Valente, M. A. L. (2011). Marco legal das licitações e compras sustentáveis na administração pública. Brasília: Biblioteca Digital Câmara. Retrieved from http://bd.camara.gov.br/bd/handle/bdcamara/5704

Vonortas, N. S., Bhatia, P., \& Mayer, D. P. (2011). Public procurement and innovation in the United States. The Elliott School of International Affairs. Center for International Science and Technology Policy. Retrieved from https://www.ige.unicamp.br/spec/wp-content/uploads/sites/15/2015/07/Report_Public-Procurement_2011.pdf

\section{Copyrights}

Copyright for this article is retained by the author(s), with first publication rights granted to the journal.

This is an open-access article distributed under the terms and conditions of the Creative Commons Attribution license (http://creativecommons.org/licenses/by/4.0/). 